\title{
ГЕНЕЗИС ИМПЛЕМЕНТАЦИИ НОРМ МЕЖДУНАРОДНОГО ПРАВА В ВОЕННОЙ И ПОГРАНИЧНОЙ СФЕРАХ: ПЕРИОДЫ И ФАКТОРЫ
}

\begin{abstract}
Аннотация: В статье раскрывается развитие периодов имплементации международного права во внутреннее законодательство России. Особенность данного подхода заключается в том, что основанием для периодизации используются этапы развития государства, а также влияние трех постоянных факторов: соииально-культурного, соичильно-экономического и классово-политического. Новизна данной статьи состоит в малоизученности аспекта имплементации в военной и пограничной сферах. Цель - попытка выявить периодизацию и доказать ее целесообразность с использованием исторического метода исследования.
\end{abstract}

Ключевые слова: международное право, внутригосударственное право, имплементация, законодательство, методь и способы национально-правовой имплементации.

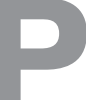
азвитие и становление имплементации международных норм во внутригосударственное право всегда было предметом исследования многих ученых. Связано это в первую очередь с тем, что международное право, как особая правовая система, складывается и развивается с возникновением государств и зарождением системы определенных отношений между ними ${ }^{1}$. С течением времени, принципы, общеобязательные права, другие основополагающие нормы, стали распространяться на все большее количество государств, затрагивая практически все отрасли современного развития: экономика, политика, право и др. Не осталась в стороне и военная сфера, в том числе защита и охрана государственной границы (пограничная деятельность).

Генезис, в соответствии с Большой советской энциклопедией - это «происхождение, возникновение; в более широком смысле, это зарождение и последующий процесс развития, приведший к определённому состоянию, виду, явлению»². Таким образом, создание международных норм - это целый механизм, в котором задействованы определённые государственные функции. Например, Общество, создавая всеми выполняемые правила поведения, одновременно продумывало, каким образом эти поведения будут выполнены и проконтролированы ${ }^{3}$ (роль государства).

${ }^{1}$ Шлянцев Д.А. Международное право: учебник, М.: Юстицинформ, 2006. С. 1

${ }^{2}$ Большая советская энциклопедия. - М.: Советская энциклопедия. 1969-1978.

${ }^{3}$ Подробнее см.: Варданяни Г.К. Социальный генезис права: гештальтсоциологический анализ : Дисс. ... канд. соц. наук. 22.00.01, M. -2008
Развитие имплементации норм международного права не может происходить самостоятельно или хаотично. Всегда существует внешняя среда, влияющая на развитие данного процесса. По мнению автора, данная внешняя среда совпадает с факторами развития права, а именно:

- социально-культурный фактор, который обусловлен социальной значимостью и возможностью человека в обществе, его сознанию, развитию и потребностях. Так появляются права и обязанности, которые также должны быть юридически закреплены государством. И особая роль отводится руководству государства, правителю (ям), а также всем, обладающим политической волей и возможностью влияния на общество.

- социально-экономический фактор, связанного в первую очередь с появлением частной собственности. Это порождает революцию в сфере материальных отношений, которая изменила первобытно-общинный строй, подняв цивилизацию на новый уровень. Отношения собственности, имущественные, товарно-рыночные, любые материальные (оплачиваемые) отношения - это правовые отношения, имеющие экономическое содержание. И подобные отношения без правовой составляющей существовать не могут.

- классово-политический фактор, под действием которого право становится сдерживающим элементом от диктатуры и абсолютного тоталитаризма, уравнивая в правах и обязанностях всех граждан определенного государства. При нарушении этого сдерживания в государстве может произойти революция.

Таким образом, генезис имплементации международного права имеет место только при наличии перечисленных выше факторов (по отдельности или в совокупности), так как при отсутствии экономики, социума или определенного класса право существовать не может, а значит и развиваться тоже. 
Учитывая данные факторы, а также мнения ученых о периодах развития права ${ }^{4}$, автор предлагает совместить их и таким образом выделить периоды развития норм международного права в военной сфере, а также ее пограничной отрасли. За основу предлагается взять соответствующие этапы развития государства, но разделение на подэтапы будет зависеть от правителей, принятых правовых актов, событий и явлений, произошедших в российском государстве (учет факторов генезиса права).

Итак, автор предлагает следующую периодизацию норм международного права в военной и пограничной сферах:

Императорский период (Х в. - 1861 г.). Начальный этап (в рабовладельческом периоде имплементации как таковой не существовало), особенность которого в том, что имплементация норм международного права только начинает зарождаться и происходит это под влиянием социально-культурного фактора, при котором государство развивается благодаря готовности общества и деятельности правителя. Культура принимает значительное участие в формировании права. Важная роль отводится Петру $\mathrm{I}^{5}$, который произвел систематизацию военно-правовых норм, создал Воинские Артикулы 1715 г. и воинские уставы 1716 и 1720 гг., которые также затрагивали некоторые вопросы пограничного характера. Эти документы были составлены на основе нормативной базы развитых европейских государств ${ }^{6}$. Также имплементируются первые

${ }^{4}$ См. например: Шлянцев Д.А. Международное право. М.: Юстицинформ, 2006. - С. 2; Левин Д.Б. История международного права, М., 1962, - С. 4; Василенко В.А. Основы теории международного права. Киев, 1988, - С. 4 6; Грабарь В.Э. Первоначальное значение римского термина jus gentium // Ученые записки Тартуского университета. Тарту, 1964. Вып.148. - С. 8-9; Мартенс Ф. Современное международное право цивилизованных народов, - СПб., 1905 , т. 2, - С. 46; Таубе М. История зарождения современного международного права. СПб, 1894.Т.1. - С. 20; Пацащия М. Ш. К вопросу о происхождении международного права : ФЕМИС. Ежегодник истории права и правоведения. Выпуск 1. - М: МГИУ, 2000. URL: http://www.law.edu.ru/doc/document.asp?docID=1135823 (дата обращения: 30.08.2012); Л. Опенгеймер. Международное право, М., 1998. т.1, п/т.1. - С. 92-96; Лукашук И.И. Международное право. Общая часть. Москва, 1997. С.40. Дискуссионность вопроса о возникновении международного права в международно-правовой науке практически общепризнанна. См.: Курс международного права в 7 томах. Т.1, М., 1989. - С. 30; Корякин В.М. Введение в теорию военного права (монография) : Военное право в XXI веке // Российский военно-правовой сборник № 9: Военное право в XXI веке. Серия «Право в Вооруженных Силах - консультант». - М.: За права военнослужащих, 2007, Вып. 73. - С. 11-119

${ }^{5}$ См.: Гаврищук В.В. Строительство Российской армии в XVIII в. Историографическое исследование: Автореф. дис. ... докт. истатья наук. М., 1999. С. 24.

${ }^{6}$ Предполагается, что данные документы не были точной копией зарубежных правовых актов, скорее, следует говорить о заимствовании положительного опыта (прим. автора). принципы международного права. Например, «принцип свободы открытого моря», чему в немалой степени способствовала провозглашенная Россией 28 февраля 1780 г. Декларация о вооруженном нейтралитете, требовавшая обеспечение свободы морского судоходства для нейтральных государств ${ }^{7}$. На основе этого были проведены различные конгрессы: Венский конгресс 1814 - 1815 гг. (породил возникновение постоянного нейтралитета Швейцарии, содействовал запрещению работорговли, развитию дипломатического права, становлению статуса международных рек), Парижский конгресс 1856 г. (запретил захват, разграбление или потопление судов воюющих государств, а также нейтральных стран; объявил нейтрализованным Черное море) и др.

Пограничный вопрос в основе своей затрагивает режим морских пространств. В данном периоде государства не могли договориться об общем использовании территориального моря. Одни страны (Англия, Венеция, Генуя, Испания, Португалия) предлагали устанавливать свой суверенитет над прибрежными водами и частями вод, другие (Нидерланды, Франция) - все моря и океаны общие и не должны принадлежать какому-либо государству. В итоге в XIV в. был издан сборник «Консолато дель маре» («Морской сборник»), содержавший правила нейтралитета, положения, касавшиеся военной контрабанды, а также устанавливавший ширину территориальных вод государства -3 мили.

2. Капиталистический период (1861 - 1917 гг.). На первый план выходят вопросы войны, а право войны начинает приобретать современные черты. Так, с Россией заключались двусторонние и многосторонние международные соглашения, а сама война переставала играть роль политического явления и акта вооруженной борьбы - в большей степени это стал юридический процесс, в котором нормы права все больше определяют способ ее ведения, лицо и характер и тем самым создают предпосылки для обеспечения прочного мира ${ }^{8}$. Проводятся многочисленные форумы и конференции по регулированию вопросов военных действий (в том числе, в пограничных районах), в которых Россия становится активным участником: Женевская конференция 1864 г., СанктПетербургская конференция 1868 г., Брюссельская конференция 1867 г., Гаагские конференции 1899 и 1907 гг. Итогом становится имплементация норм международного права в право российское путем принятия таких документов, как «Наказ Русской армии о законах и обычаях сухопутной войны», высочайше утвержденный 14 июля 1904 г. 27 апреля 1912 г. Этот Наказ был включен

${ }^{7}$ См. подробнее: Фомичев П.Е. Российско-португальские торговоэкономические и дипломатические отношения в XVIII - начале XIX веков: Дисс.... канд. юр. наук \СПб, 2005.

${ }^{8}$ См.: Военное законодательство Российской империи. С. 387. 


\section{Право и политика $1(157) \cdot 2013$}

в качестве приложений к Уставам полевой службы 1904 и 1912 гг. Преемственную роль берет на себя социальноэкономический фактор, в котором экономика становится основой государственного развития и связанных с ним элементов: право, политика и т.д. Капитал определяет, в какую сторону необходимо развиваться государству.

3. Современный период (1917 г. - по н.в.). Созданные международные организации, в том числе Организация Объединенных Наций (далее - ООН), берут на себя роль источника имплементации. По мнению Н.В. Миронова, история советского права свидетельствует о добросовестном отношении Советского государства к взятым на себя международным обязательствам и их согласованию с национальным законодательством 9 . Так, в Конституции СССР было закреплено 10 принципов Заключительного акта Совещания по безопасности и сотрудничеству в Европе, на основе которых строятся отношения СССР с другими государствами, в том числе по пограничным вопросам. Например, регламентация юрисдикции государства при совершении преступлений на борту иностранных невоенных судов во время пребывания их в территориальных водах, внутренних водах и портах $\mathrm{CCCP}^{10}$. Российская Федерация продолжила практику имплементации норм международного права в свое национальное законодательство. Так, некоторые положения Устава ООН были закреплены и в Основном законе России - Конституции Российской Федерации.

Кроме Конституции Российской Федерации некоторые предписания международно-правовых норм включаются в другие нормативные правовые акты ${ }^{11}$. Так, согласно ст. 4 Федерального закона от 3 апреля 1995 г. «О федеральной службе безопасности», правовую основу деятельности федеральной службы безопасности составляют Конституция Российской Федерации, Федеральный закон «О федеральной службе безопасности», другие федеральные законы и иные нормативные правовые акты Российской Федерации. Отдельно прописано: «Деятельность федеральной службы безопасности осуществляется также в соответствии с международными договорами Российской Федерации» ${ }^{12}$.

\footnotetext{
${ }^{9}$ Миронов Н.В. Советское законодательство и международное право. М., 1968.

${ }^{10}$ См. п. 5, ст. 30 Закона СССР от 24 ноября 1982 г. «О государственной границе СССР»

${ }^{11}$ Марочкин С.Ю. Действие и реализация норм международного права в правовой системе Российской Федерации: Монография. М.: Норма, Инфра-М, 2011.

${ }^{12}$ К таким договорам можно отнести: Соглашение между Правительством Российской Федерации и Правительством Республики Индии от 12 ноября 2007 г. о сотрудничестве в борьбе с незаконным оборотом наркотических средств, психотропных веществ и их прекурсоров; Соглашение между Правительством Российской Федерации и Правительством Соединенных Штатов Америки от 25 сентября 2002 г. о сотрудничестве в осуществлении правоохра-
}

В пограничной сфере также заметны изменения. Так, имплементация становится основой для многих других правовых актов России - Федеральных законов «О Государственной границы», «О континентальном шельфе Российской Федерации», «О внутренних морских водах, территориальном море и прилежащей зоне Российской Федерации» и др ${ }^{13}$. Благодаря этому, решаются такие актуальные вопросы, как делимитация морских пространств, определение государственной территории, взаимодействие в пограничной деятельности и т.п.

При этом имплементация в определениях пограничной направленности не прослеживается - она касается лишь только принципов и некоторых положений, которые разграничивают сушу, воды и морские пространства. А такое понятие как «пограничное пространство» не закреплено не только в праве Российской Федерации, но и в нормах международного права ${ }^{14}$.

Примером развития имплементации в пограничной сфере можно также считать выработку первых действенных мер по борьбе с незаконной миграцией. ${ }^{15}$ Основу данного направления составляют общепризнанные принципы и нормы международного права и международные договоры Российской Федерации ${ }^{16}$. Основные права и свободы человека, распространяемые и на мигрантов, закреплены во Всеобщей декларации прав человека 1948 г., Международных пактах о правах человека 1966 г. и иных соглашениях, заключенных в этой области ${ }^{17}$. Данные положения нашли свое отражение и в Конституции

нительной деятельности и контроля за наркотиками; Соглашение между Правительством Российской Федерации и Правительством Республики Словении от 15 мая 2001 г. о сотрудничестве в области борьбы с организованной преступностью, незаконным оборотом наркотиков, терроризмом и иными видами преступлений.

${ }^{13}$ Подробнее см.: Батырь В.А. Имплементация норм международного гуманитарного права в военном законодательстве Российской Федерации: дисс. канд. юр. наук, 20.02.03. - М.: ВУ, 1999.

${ }^{14}$ Фокин В.B. Теория искусства охраны государственной границы: отражение изменений (1991-2003 гг.) //Сборник статей №16. - М.: Международная академия информатизации, Отделения погранологии, 2010. - С.113

15 Червоненко В.Ф. Международно - правовые основы борьбы с незаконной миграцией // Миграционное право. - 2007. - №1 . - С. $12-14$

${ }^{16}$ Международные договоры Российской Федерации заключаются с иностранными государствами, а также с международными организациями от имени Российской Федерации (межгосударственные договоры), от имени Правительства Российской Федерации (межправительственные договоры), от имени федеральных органов исполнительной власти (договоры межведомственного характера).

${ }^{17}$ Буканова О.А. Имплементация международно - правовых норм в российское законодательство как один из основных путей совершенствования нормативной правовой базы, регламентирующей пропуск через государственную границу // URL: www.gosbook.ru/ system/files/.../Bukanova-propusk_gosgranicu.doc (дата обращения: 26.02.2012) 
Российской Федерации. Одними из наиболее важных вопросов в борьбе с незаконной миграцией являются меры пограничного контроля. Такие меры охватываются положениями Протокола ${ }^{18}$

Некоторые ученые приводят более конкретные примеры имплементации. Так, О.А. Буканова в своих трудах рассматривает следующее: схожие нормы содержит третий раздел (Прибытие и отбытие лиц) приложения 1 к Конвенции по облегчению международного морского судоходства (Лондон, 9 апреля 1965 г.). В результате анализа данного приложения было выявлено, что пункт 3.9 раскрывает ряд положений необходимых для дополнения в п. 6 «Правил осуществления контроля в пунктах пропуска через государственную границу Российской Федерации» (утв. постановлением Правительства Российской Федерации от 20 ноября 2008 г. №872), а также в п.14 Положения о применении средств и методов контроля при осуществлении пропуска лиц, транспортных средств, грузов, товаров и животных через государственную границу Российской Федерации (утв. постановлением Правительства Российской Федерации от 2 февраля 2005 г. №50), а именно: а) досмотр (багажа) следует производить на выборочной основе (при прибытии); б) по возможности не производить досмотр (при убытии) ${ }^{19} . »$

В заключении по данному периоду, можно сказать, что в нем соблюдены одновременно два фактора: классово-политический и социально-культурный. Первый возникает в связи с революционными движениями того времени, разделением на классы и переход к пролетариату, второй - в новом этапе развития общества как советского народа. Культура видоизменяется и, отторгая монархические достижения, начинает развиваться по новому.

Таким образом, итогом статьи можно считать следующее:

Выделение трех периодов развития имплементации норм международного права в военной и пограничной сферах (Императорский период (Х в. - 1861 г.); Капиталистический период (1861 - 1917 гг.) и Современный период (1917 г. - по н.в.) - совмещает в себе точки зрения различных ученых на генезис как международного права, так и военного права в Российской Федерации.

\footnotetext{
18 Протокол против незаконного ввоза мигрантов по суше, морю и воздуху, дополняющий Конвенцию Организации Объединенных Наций против транснациональной организованной преступности (принят резолюцией 55/25 Генеральной Ассамблеи ООН от 15 ноября 2000 г.) // Собр. законодательства Рос. Федерации. - 2004. - № 18, статья 1684.

${ }^{19}$ Буканова O.A. Имплементация международно-правовых норм в российское законодательство как один из основных путей совершенствования нормативной правовой базы, регламентирующей пропуск через государственную границу // URL: www.gosbook.ru/ system/files/.../Bukanova-propusk_gosgranicu.doc (дата обращения: 26.02.2012)
}

Также соблюдаются этапы развития государства и факты (явления) происходящие в нем. Особое внимание необходимо уделить факторам, влияющим на развитие права: социально-культурному, социально-экономическому и классово-политическому.

Несмотря на то, что именно в современном периоде произошли все те изменения, которые действуют и в настоящее время - все этапы заслуживают внимания и исследования. В любом периоде существуют свои особые события, так или иначе повлиявшие на развитие имплементации:

a) императорский период: деятельность Петра I, направленная на заимствование у европейских стран некоторых положений. Так были созданы Воинские Артикулы 1715 г. и воинские уставы 1716 и 1720 гг. (социально-культурный фактор);

б) капиталистический период: нарастающая роль права войны, а также проходящие международные конференции: Женевская конференция 1864 г., СанктПетербургская конференция 1868 г., Брюссельская конференция 1867 г., Гаагские конференции 1899 и 1907 гг. (социально-экономический фактор);

в) современный период: создание $\mathrm{OOH}$ и принятие Конвенции (например, Конвенция ООН 1982 г.), что в дальнейшем будет использовано в законодательстве Российской Федерации (классово-политический и социально-культурный).

Изучение генезиса имплементации норм международного права в военной и пограничной сферах позволяет более объективно проводить исследование современного состояния международного права, а также основных направлений его имплементации в законодательство Российской Федерации в сфере пограничной деятельности.

\section{Библиография:}

1. Батырь В.А. Имплементация норм международного гуманитарного права в военном законодательстве Российской Федерации: дисс. канд. юр. наук, 20.02.03. - М.: ВУ, 1999.

2. Большая советская энциклопедия. - М.: Советская энциклопедия. 1969 - 1978.

3. Буканова О.А. Имплементация международно-правовых норм в российское законодательство как один из основных путей совершенствования нормативной правовой базы, регламентирующей пропуск через государственную границу // URL: www.gosbook.ru/ system/files/.../Bukanova-propusk_gosgranicu.doc (дата обращения: 26.02.2012)

4. Варданянц Г.К. Социальный генезис права: гештальтсоциологический анализ : Дисс. ... канд. соц. наук. 22.00.01, M. - 2008 . 
5. Василенко В.А. Основы теории международного права. Киев, 1988, - С. 46

6. Военное законодательство Российской империи. С. 387.

7. Гаврищук В.В. Строительство Российской армии в XVIII в. Историографическое исследование: Автореф. дис. ... докт. истатья наук. М., 1999. С. 24.

8. Грабарь В.Э. Первоначальное значение римского термина jus gentium // Ученые записки Тартуского университета. Тарту, 1964. Вып.148. - С. 8-9

9. Корякин В.М. Введение в теорию военного права (монография) : Военное право в XXI веке // Российский военно-правовой сборник № 9: Военное право в XXI веке. Серия «Право в Вооруженных Силах - консультант». - М.: За права военнослужащих, 2007, Вып. 73. - С. 11-119

10. Левин Д.Б. История международного права, М., 1962,- С. 4

11. Лукашук И.И. Международное право. Общая часть. Москва, 1997. С.40. Дискуссионность вопроса о возникновении международного права в международно-правовой науке практически общепризнанна. См.: Курс международного права в 7 томах. T.1, М., 1989. - С. 30

12. Марочкин С.Ю. Действие и реализация норм международного права в правовой системе Российской Федерации: Монография. М.: Норма, Инфра-М, 2011.

13. Мартенс Ф. Современное международное право цивилизованных народов, - СПб., 1905, т. 2,C. 46

14. Миронов Н.В. Советское законодательство и международное право. М., 1968.

15. Пацация М. Ш. К вопросу о происхождении международного права : ФЕМИС. Ежегодник истории права и правоведения. Выпуск 1. - M: МГИУ, 2000. URL: http://www.law.edu.ru/doc/ document.asp?docID=1135823 (дата обращения: 30.08.2012);

16. Л. Опенгеймер. Международное право, М., 1998. т.1, п/т.1. - С. $92-96$

17. Таубе М. История зарождения современного международного права. СПб, 1894.T.1. - С. 20

18. Фокин В.В. Теория искусства охраны государственной границы: отражение изменений (1991-2003 гг.) //Сборник статей №16. - М.: Международная академия информатизации, Отделения погранологии, 2010. - С.113

19. Червоненко В.Ф. Международно - правовые основы борьбы с незаконной миграцией // Миграционное право. - 2007. - №1. - С. 12-14.

20. Шлянцев Д.А. Международное право. М.: Юстицинформ, 2006. - С. 2

\section{References (transliteration):}

1. Batyr' V.A. Implementatsiya norm mezhdunarodnogo gumanitarnogo prava v voennom zakonodatel'stve Rossiyskoy Federatsii: diss. kand. yur. nauk, 20.02.03. - M.: VU, 1999.

2. Bukanova O.A. Implementatsiya mezhdunarodnopravovykh norm v rossiyskoe zakonodatel'stvo kak odin iz osnovnykh putey sovershenstvovaniya normativnoy pravovoy bazy, reglamentiruyushchey propusk cherez gosudarstvennuyu granitsu // URL: www.gosbook.ru/system/files/.../Bukanovapropusk_gosgranicu.doc (data obrashcheniya: 26.02.2012)

3. Vardanyants G.K. Sotsial'nyy genezis prava: geshtal'tsotsiologicheskiy analiz : Diss. ... kand. sots. nauk. 22.00.01, M. - 2008.

4. Vasilenko V.A. Osnovy teorii mezhdunarodnogo prava. Kiev, 1988, S. 46

5. Gavrishchuk V.V. Stroitel'stvo Rossiyskoy armii v XVIII v. Istoriograficheskoe issledovanie: Avtoref. dis. ... dokt. istat'ya nauk. M., 1999. S. 24.

6. Grabar' V.E. Pervonachal'noe znachenie rimskogo termina jus gentium // Uchenye zapiski Tartuskogo universiteta. Tartu, 1964. Vyp.148.; S. 8-9

7. Koryakin V.M. Vvedenie v teoriyu voennogo prava (monografiya) : Voennoe pravo v XXI veke // Rossiyskiy voenno-pravovoy sbornik № 9: Voennoe pravo v XXI veke. Seriya «Pravo v Vooruzhennykh Silakh - konsul'tant». - M.: Za prava voennosluzhashchikh, 2007, Vyp. 73.; S. 11-119

8. Levin D.B. Istoriya mezhdunarodnogo prava, M., 1962,; S. 4

9. Lukashuk I.I. Mezhdunarodnoe pravo. Obshchaya chast'. Moskva, 1997. S.40. Diskussionnost' voprosa o vozniknovenii mezhdunarodnogo prava $\mathrm{v}$ mezhdunarodno-pravovoy nauke prakticheski obshchepriznanna. Sm.: Kurs mezhdunarodnogo prava v 7 tomakh. T.1, M., 1989.; S. 30

10. Marochkin S.Yu. Deystvie i realizatsiya norm mezhdunarodnogo prava v pravovoy sisteme Rossiyskoy Federatsii: Monografiya. M.: Norma, Infra-M, 2011.

11. Martens F. Sovremennoe mezhdunarodnoe pravo tsivilizovannykh narodov, - SPb., 1905, t. 2, S. 46

12. Mironov N.V. Sovetskoe zakonodatel'stvo i mezhdunarodnoe pravo. M., 1968.

13. Patsatsiya M. Sh. K voprosu o proiskhozhdenii mezhdunarodnogo prava : FEMIS. Ezhegodnik istorii prava i pravovedeniya. Vypusk 1. - M: MGIU, 2000. URL: http://www.law.edu.ru/doc/ document.asp?docID=1135823 (data obrashcheniya: 30.08.2012); 
История государства и права

14. L. Opengeymer. Mezhdunarodnoe pravo, M., 1998. t.1, p/t.1. S. 92-96

15. Taube M. Istoriya zarozhdeniya sovremennogo mezhdunarodnogo prava. SPb, 1894.T.1.; S. 20

16. Fokin V.V. Teoriya iskusstva okhrany gosudarstvennoy granitsy: otrazhenie izmeneniy (1991-2003 gg.) //Sbornik statey №16. - M.: Mezhdunarodnaya akademiya informatizatsii, Otdeleniya pogranologii, 2010. - S.113

17. Chervonenko V.F. Mezhdunarodno - pravovye osnovy bor'by s nezakonnoy migratsiey // Migratsionnoe pravo. - 2007. - №1. - S. 12-14.

18. Shlyantsev D.A. Mezhdunarodnoe pravo. M.: Yustitsinform, 2006. S. 2 